http://dx.doi.org/10.11646/zoosymposia.15.1.9

http://zoobank.org/urn:lsid:zoobank.org:pub:D969DD55-1299-47E9-9C17-47F259831F58

\title{
A project for analyzing the ecology and phylogeny of western Pacific echinoids
}

\author{
K. KANAZAWA ${ }^{1 *}$, M. SAITOH ${ }^{2}$, N. WAKAYAMA ${ }^{2}$, M. OBUCHI $^{3}$, S. NAKACHI ${ }^{4}$ \& A. $\mathrm{KROH}^{5}$ \\ ${ }^{\prime}$ Department of Biological Sciences, Faculty of Science, Kanagawa University, Hiratsuka City, Kanagawa 259-1293, Japan \\ ${ }^{2}$ Research Institute for Integrated Science, Kanagawa University, Hiratsuka City, Kanagawa 259-1293, Japan \\ ${ }^{3}$ Education Center, Manazuru Town Office, Manazuru Town, Kanagawa 259-0202, Japan \\ ${ }^{4}$ Biological Institute on Kuroshio, Kuroshio Biological Research Foundation, Otsuki town, Kochi 788-0333, Japan \\ ${ }^{5}$ Geological-Paleontological Department, Natural History Museum Vienna, Vienna, Austria \\ *e-mail: kanazawa@kanagawa-u.ac.jp
}

\begin{abstract}
In 2017 we started a project to analyze the ecology and phylogeny of western Pacific echinoids. As the first step, we are establishing methods to infer their phylogenetic relationships using molecular data; we developed effective methods to obtain complete mitochondrial DNA sequences, and determined their effectiveness in phylogenetic analysis. We have also been gathering data concerning the ecology and systematics of Japanese extant echinoids, which arguably has among the highest genus-level diversities in the West Pacific or perhaps even in the world. We have collected 58 species from middle and southern Japan representing 48 genera. In the next year, we will collect sea urchins from northern Japan, and within 2 years we will finish collecting data on ecology and systematics of Japanese echinoids, and provide a set of standardized data that will be useful for many researchers studying western Pacific echinoids. At that time, we will start comparative analyses of echinoid faunas distributed in the western Pacific.
\end{abstract}

Key words: echinoid, Pacific, ecology, phylogeny

\section{Introduction}

The western Pacific Ocean extending from the Kamchatka Peninsula to Australia is a fascinating region for echinoid researchers, because there is a variety of environments with subarctic to tropical climates, and strong warm and cold currents. Geological variation, forearc islands, basins, volcanic islands, and trenches produce various geomorphologies such as coral reefs, sand beaches, and rocky shores, resulting in the most diverse echinoid fauna in the world. The western Pacific sea urchins have been studied since the first half of the 19th century (Agassiz 1872-74, 1879, 1881; Agassiz and Clark 1907a-b, 1908, 1909; Clark 1912, 1914, 1917; Mortensen 1928, 1935, 1940, 1943a-b, 1948a-b, 1950, 1951). An overview of western Pacific echinoid faunas can be derived from the echinoid species described in the great monograph of Mortensen (1928-1951). Since his work, however, no comprehensive study on the western Pacific echinoids has been done until today, though several regional studies for some restricted areas were carried out; e.g. Fell (1963) for New Zealand; Nisiyama $(1966,1968)$ and Shigei (1986) for Japan; Lane et al. (2000) for South China; Miskelly (2002) for Australia; van Noordenburg (2008) and Mooi \& Munguia (2014) for the Philippines. Mooi \& Munguia (2014) showed high species richness of the Philippines echinoid fauna; according to their estimates, only half the number of species seen in the Philippines have been recorded from India, Malaysia, and Indonesia combined, and there are more than twice as many echinoid species in the Philippines as in the Gulf of Mexico and Caribbean Sea together. The Philippines fauna includes representatives of every extant order and over $70 \%$ of the extant families in the world. They suggest that this provides support for the idea that the Philippines is a center of overlap for many echinoid species occurring in the Philippines (Gaither and Rocha 2013). 
Since the 1990s, phylogenetic relationships of echinoids have been analyzed based on molecular data that often encouraged evolutionary discussion in terms of developmental biology. For the western Pacific echinoids, some interesting findings have been reported, for example, speciation in Echinometra mathaei living in the Tropical Pacific (Matsuoka \& Hatanaka 1991; Palumbi et al. 1997); close relationship between Acanthocidaris from Japan and Heliocidaris from Australia (Kinjo et al. 2008), phylogeny and evolution of temnopleurid echinoids (Jeffery et al. 2003). The timing is good to re-examine the phylogenetic relationships of the western Pacific echinoids based on molecular data.

\section{Project on the western Pacific sea urchins}

In 2017, we started a project to analyze the ecology and phylogenetics of western Pacific echinoids. In the first step, we are establishing methods to infer the phylogenetic relationships among families or genera using molecular data. To do this, we developed effective methods for DNA extraction and PCR to obtain complete mitochondrial DNA sequences, and determined the effectiveness of phylogenetic analyses based on complete mitochondrial DNA sequences. The preliminary result is presented by Wakayama et al. in this proceedings volume. In addition, we are assessing the ecology and systematics of Japanese extant echinoids, characteristics of which are mentioned below. For many sea urchins, their ecology can be observed while collecting the specimens by scuba. A preliminary report on 58 species from 22 families of 9 orders from middle and southern Japan is presented by Saitoh et al. in this proceedings volume.

In the next year, we will collect sea urchins from northern Japan, and within 2 years we will finish analyzing Japanese echinoids for their ecology and phylogeny, and provide a set of standardized data that will be useful for many researchers studying western Pacific echinoids. We will then start comparative analyses of echinoid faunas distributed in the western Pacific. Anyone who is interested in this project and would like to join it is welcome.

\section{Sea urchins around Japan}

Systematic studies on Japanese extant echinoids had been carried out since the middle of the 19th century: Agassiz (1863, 1872-74, 1879, 1881), Döderlein (1885, 1887), Yoshiwara (1897, 1898a-b, 1900, 1901), Tokunaga (1904, 1905, 1906a-b, 1907, 1908), Mortensen (1904, 1928, 1930, 1935, 1940, 1943a-b, 1948a-b, 1950, 1951), Agassiz and Clark (1907a-b, 1908, 1909), Clark (1912, 1914, 1917, 1925), Utinomi (1949, 1952, 1954, 1960a-b, 1965, 1979), Nisiyama (1966, 1968), Shigei (1971, 1973, 1974, 1975, 1981a-b, 1982ab, 1986). Today, 116 species from 107 genera are known from Japan and adjacent regions according to Shigei (1986) and our investigations.

The number of species in Japan is about half of the Philippines, but interestingly, the Japanese fauna has 7 more genera than occur in the Philippines. This difference might be caused by the level of knowledge of the taxonomic relationships among these taxa; in tropical regions such as the Philippines, the taxa are much more poorly known (Mooi personal comm. 2018). However, it might be ascribed to the geographic location of Japan. Japan is located from 20 to 46 degrees north latitude-the distance between the northern and southern limits is about $4000 \mathrm{~km}$. The northernmost region is situated in the subarctic zone. In the south, the climate changes from cold temperate to warm temperate to subtropical. Off the Pacific side of Honshu Island, the main island of Japan, the Japan Trench reaches a depth of $8020 \mathrm{~m}$, and two strong ocean currents, the cold Oyashio Current from the north and the warm Kuroshio Current from the South collide. Corresponding to these varied environmental conditions, four elements in Japanese echinoid fauna can be recognized. Northern elements are represented by Strongylocentrotus intermedius and Echinarachinius parma; sea urchins of these genera can also be found in Russia and Alaska. Endemic elements include Pseudocentrotus depressus, Hemicentrotus pulcherrimus, and Scaphechinus mirabilis; they appear to have speciated around Japan, based on their fossil record. Deep-sea elements are mainly composed of cidarids like Stereocidaris sceptriferoides and Goniocidaris mikado, and echinothurioids such as Phormosoma bursarium and Hygorosoma hoplacantha. Southern elements contain the genera common to the Philippines. Because of this rich diversity, it is assumed that a comprehensive study of Japanese echinoids carried out by this project will contribute to understanding the western Pacific echinoids as well. 


\section{Acknowledgments}

The authors thank Kazuhito Abe (Okinokuni Diving), Yuki Abe (Okinokuni Diving), Kadzuho Yamamoto (The 101), the staff of the Misaki Marine Biological Station and the crew of the R/V Seisui-maru of Mie University for their kind guidance and help during the field investigations. We also thank Dr. Rich Mooi and Dr. Omri Bronstein for their extensive comments to improve the manuscript. This study was supported by a research grant for collaborative projects of Kanagawa University.

\section{References}

Agassiz, A. (1863) Synopsis of the echinoids collected by Dr. W. Stimpson on the North Pacific Exploring Expedition under the command of Captains Ringgold and Rodgers. Proceedings of the Academy of Natural Sciences of Philadelphia, 15, 352361.

Agassiz, A. (1872-1874) Revision of the Echini. Memoirs of the Museum of Comparative Zoölogy at Harvard College 3, pt. 12: i-xii, 1-378, pls. 1-49 (1872); pt. 3: 379-628+1, pls. 50-77 (1873); pt. 4: 629-762, pls. 78-94 (1874). https://doi.org/10.1136/bmj.1.628.50-a

Agassiz, A. (1879) Preliminary report on the Echini of the Exploring Expedition of H.M.S "Challenger", Sir C. Wyville Thomson Chief of Civilian Staff. Proceedings of the American Academy of Arts and Sciences, new series, 6, 190-212. https://doi.org/10.2307/25138537

Agassiz, A. (1881) Report on the scientific results of the voyage of H.M.S. "Challenger" during the years 1873-1876, Zoology, Vol. III, Part IX, Report on the Echinoidea. Longmans \& Company, London, viii+321 pp.

Agassiz, A. \& Clark, H.L. (1907a) Hawaiian and other Pacific Echini. The Cidaridae. Memoirs of the Museum of Comparative Zoology at Harvard College, 34, 1-42.

Agassiz, A. \& Clark, H.L. (1907b) Preliminary report on the Echini collected in 1906, from May to December, among the Aleutian Islands, in Bering Sea, and along the coasts of Kamchatka, Saghalin, Korea, and Japan, by U.S. Fish Commission steamer "Albatross", in charge of Lieut.-Commander L. M. Garrett, U.S.N., commanding. Bulletin of the Museum of Comparative Zoölogy at Harvard College in Cambridge, 51, 107-139.

Agassiz, A. \& Clark, H.L. (1908) Hawaiian and other Pacific Echini. The Salenidæ, Arbaciadæ, Aspidodiadematidæ, and Diadematidæ. Memoirs of the Museum of Comparative Zoölogy at Harvard College, 34, 43-132.

Agassiz, A. \& Clark, H.L. (1909) Hawaiian and other Pacific Echini. The Echinothuridae. Memoirs of the Museum of Comparative Zoology at Harvard College, 34, 135-203.

Clark, H.L. (1912) Hawaiian and other Pacific Echini. The Pedinidae, Phymosomatidae, Stomopneustidae, and Echinometridae. Memoirs of the Museum of Comparative Zoology at Harvard College, 34, 205-383. https://doi.org/10.5962/bhl.title.3820

Clark, H.L. (1914) Hawaiian and other Pacific Echini. The Clypeasteridae, Arachnoididae, Laganidae, Fibulariidae, and Scutellidae. Memoirs of the Museum of Comparative Zoology at Harvard College, 46, 1-80.

Clark, H.L. (1917) Hawaiian and other Pacific Echini. The Echinoneidae, Nucleolitidae, Urechinida, Echinocorythidae, Calymnidae, Pourtalesiidae, Palaeostomatidae, Aeropside, Palaeopneustidae, Hemiasteridae, and Spatangidae. Memoirs of the Museum of Comparative Zoology at Harvard College, 46, 81-283.

Clark, H.L. (1925) A Catalogue of the Recent Sea-Urchins (Echinoidea) in the Collection of the British Museum (Natural History). Oxford University Press, London, $250 \mathrm{pp}$.

Döderlein, L. (1885) Seeigel von Japan und den Liu-Kiu Inseln. Archiv für Naturgeschichte, 51, 73-112. https://doi.org/10.5962/bhl.part.1569

Döderlein, L. (1887) Die Japanischen Seeigel. I. Theil. Familie Cidaridae und Saleniidae. E. Schweizerbartsche Verlagsbuchhandlung, Stuttgart, $59 \mathrm{pp}$.

Fell, H.B. (1963) The Spatangid Echinoids of New Zealand. Zoology Publications from Victoria University of Wellington, 32 , $1-8$.

Gaither, M.R. \& Rocha, L.A. (2013) Origins of species richness in the Indo-Malay-Philippine biodiversity hotspot: evidence for the centre of overlap hypothesis. Journal of Biogeography, 40, 1638-1648. https://doi.org/10.1111/jbi.12126

Jeffery, C.H., Emlet, R.B. \& Littlewood, D.T.J. (2003) Phylogeny and evolution of developmental mode in temnopleurid echinoids. Molecular Phylogenetics and Evolution, 28, 99-118. https://doi.org/10.1016/S1055-7903(03)00030-7

Kinjo, S., Shirayama, Y. \& Wada, H. (2008) Evolutionary history of larval skeletal morphology in sea urchin Echinometridae (Echinoidea: Echinodermata) as deduced from mitochondrial DNA molecular phylogeny. Evolution \& Development, 10, 
$632-641$.

https://doi.org/10.1111/j.1525-142X.2008.00277.x

Lane, D.J.W., Marsh, L.M., VandenSpiegel, D. \& Rowe, F.W.E. (2000) Echinoderm fauna of the South China Sea: An inventory and analysis of distribution patterns. The Raffles Bulletin of Zoology, 2000, 459-493.

Matsuoka, N. \& Hatanaka, T. (1991) Molecular Evidence for the Existence of Four Sibling Species within the Sea-Urchin, Echinometra mathaei in Japanese Waters and their Evolutionary Relationships. Zoological Science, 8, 121-133.

Miskelly, A. (2002) Sea Urchins of Australia and the Indopacific. Capricornica Publications, Sydney, 180 pp.

Mooi, R. \& Munguia, A. (2011) Sea Urchins of the Philippines. In: Williams, G.C. \& Gosliner, T.M. (Eds.), The Coral Triangle: The 2011 Hearst Philippine Biodiversity Expedition. California Academy of Sciences, San Francisco, California, pp. 213-235.

Mortensen, T. (1904) The Danish Expedition to Siam 1899-1900. II. Echinoidea (1). Det Kongelige Danske Videnskabernes Selskabs Skrifter, Serie 7, 1, 1-124.

Mortensen, T. (1928) A Monograph of the Echinoidea. I. Cidaroidea. C. A. Reitzel \& Oxford University Press, Copenhagen \& London, $551 \mathrm{pp}$.

Mortensen, T. (1935) A Monograph of the Echinoidea. II. Bothriocidaroida, Melonechinoida, Lepidocentroida, and Stirodonta. C. A. Reitzel \& Oxford University Press, Copenhagen \& London, 647 pp.

Mortensen, T. (1940) A Monograph of the Echinoidea. III, 1. Aulodonta, with Additions to Vol. II (Lepidocentroida and Stirodonta). C. A. Reitzel, Copenhagen, 370 pp.

Mortensen, T. (1943a) A Monograph of the Echinoidea. III, 2. Camarodonta. I. Orthopsidce, Glyphocyphidce, Temnopleuridae and Toxopneustidce. C. A. Reitzel, Copenhagen, vii +553 pp.

Mortensen, T. (1943b) A Monograph of the Echinoidea. III, 3. Camarodonta. II. Echinida, Strongylocentrotidae, Parasaleniida, Echinometridae. C. A. Reitzel, Copenhagen, 446 pp.

Mortensen, T. (1948a) A Monograph of the Echinoidea. IV, 1 Holectypoida, Cassiduloida. C. A. Reitzel, Copenhagen, 371 pp.

Mortensen, T. (1948b) A Monograph of the Echinoidea. IV, 2. Clypeasteroida. Clypeasteridoe, Arachnoidce, Fibulariidae, Laganidce and Scutellidoe. C. A. Reitzel, Copenhagen, $471 \mathrm{pp}$.

Mortensen, T. (1950) A Monograph of the Echinoidea. V, 1. Spatangoida I. Protosternata, Meridosternata, Amphisternata I. Palceopneustidce, Palceostomatidoe, Aëropsidce, Toxasteridce, Micrasteridce, Hemiasteridce. C. A. Reitzel, Copenhagen, 432 pp.

Mortensen, T. (1951) A Monograph of the Echinoidea. V, 2. Spatangoida II. Amphisternata II. Spatangidce, Loveniidce, Pericosmidce, Schizasteridce, Brissidce. C. A. Reitzel, Copenhagen, 593 pp.

Nisiyama, S. (1966) The Echinoid Fauna from Japan and adjacent Regions. Part I. Paleontological Society of Japan, Special Papers, 11, i-ii, 1-277.

Nisiyama, S. (1968) The Echinoid Fauna from Japan and adjacent Regions. Part II. Paleontological Society of Japan, Special Papers, 13, i-ii, 1-491.

Palumbi, S.R., Grabowsky, G.L., Duda, T., Geyer, L. \& Tachino, N. (1997) Speciation and population genetic structure in tropical Pacific sea urchins. Evolution, 51, 1506-1517. https://doi.org/10.1111/j.1558-5646.1997.tb01474.x

Shigei, M. (1971) Distribution of littoral echinoids around the shores of the Kanto District and Izu Islands. Zoological Magazine, 80, 477. [In Japanese]

Shigei, M. (1973) A check list of echinoids found in Sagami Bay with brief note on each species. Journal of the Faculty of Science, University of Tokyo, Section 4: Zoology, 13, 1-33.

Shigei, M. (1974) Echinoids. The Systematic Zoology 8 (2)-Echinoderms. Nakayama Book Company, Tokyo, pp. 208-332. [In Japanese]

Shigei, M. (1975) A new species of the heart urchins, an extant species of Brissopatagus (Echinoidea: Spatangoida), from Sagami Bay. Journal of the Faculty of Science, University of Tokyo, Section 4: Zoology, 13, 333-339.

Shigei, M. (1981a) A study on the echinoids fauna of the East China Sea and the coastal waters of southern Korea, Kyushu, Ryukyu and Taiwan. Publications of the Seto Marine Biological Laboratory, 26, 192-241. https://doi.org/10.5134/176013

Shigei, M. (1981b) A new species of the spatangoid sea-urchin (Echinoidea; Spatangoida), Lovenia lata, from Sagami Bay. Journal of the Faculty of Science, University of Tokyo, Section 4: Zoology, 15, 81-87.

Shigei, M. (1982a) A new species of the fibulariid sea-urchin, Fibularia japonica, from Japanese waters. Publications of the Seto Marine Biological Laboratory, 27, 11-16.

https://doi.org/10.5134/176047

Shigei, M. (1982b) Echinoid fauna of the southeastern coast of the Izu Peninsula, Central Japan. Memoirs of the National Science Museum, 15, 195-200.

Shigei, M. (1986) The sea urchins of Sagami Bay collected by His Majesty the Emperor of Japan. Maruzen, Tokyo, 204 pp. 
Tokunaga, S. (1904) Japanese Echini (Plates). Zoological Magazine, 16, pls. 1-2.

Tokunaga, S. (1905) Japanese Echini (Plates). Zoological Magazine, 17, pls. 3-7.

Tokunaga, S. (1906a) Japanese Echini (Plates). Zoological Magazine, 18, pls. 8-13.

Tokunaga, S. (1906b) Japanese Echini; Explanation of all plates. Zoological Magazine, 18, appendix pp. 1-5.

Tokunaga, S. (1907) Japanese Echini (Plates). Zoological Magazine, 19, pls. 14-19.

Tokunaga, S. (1908) Japanese Echini (Plates). Zoological Magazine, 20, pls. 20-21.

Utinomi, H. (1949) Tropical sea-urchins occurring in the Kii region. Nankiseibutsu, 1, 55-56. [In Japanese]

Utinomi, H. (1952) Echinoderms dredged from off Minabe. Nankiseibutsu, 4, 9-19. [In Japanese]

Utinomi, H. (1954) A check list of echinoids found in the Kii region. Publications of the Seto Marine Biological Laboratory, 3 , 339-358. https://doi.org/10.5134/174487

Utinomi, H. (1960a) Echinoids from Hokkaido and the neighbouring subarctic waters. Publications of the Seto Marine Biological Laboratory, 3, 337-350. https://doi.org/10.5134/174645

Utinomi, H. (1960b) Echinoidea. Encyclopedia Zoologica illustrated in colours, 3 Hokuryu-kan, Tokyo, pp. 5-10. [In Japanese]

Utinomi, H. (1965) Echinoidea. New illustrated encyclopedia of the fauna of Japan,3 Hokuryu-kan, Tokyo, pp. 196-257. [In Japanese]

Utinomi, H. (1979) Echinoidea. Illustrated encyclopedia of the fauna of Japan (Newly compiled) Hokuryu-kan, Tokyo, pp. 506-513. [In Japanese]

van Noordenburg, H. (2008) Sea Urchins of the Philippines. Part I. The Irregulars. Artificial Harmonics, Utrecht, 153 pp.

Yoshiwara, S. (1897) On Two New species of Asthenosoma from the Sea of Sagami. Annotationes Zoologicae Japonenses, 1, 5-11.

Yoshiwara, S. (1898a) Preliminary notice of new Japanese echinoids. Annotationes Zoologicae Japonenses, 2, $57-61$.

Yoshiwara, S. (1898b) Japanese Echini. Zoological Magazine 10, 1-8, 73-76, 145-158, 247-250, 328-331, 439-443. [In Japanese]

Yoshiwara, S. (1900) Japanese Echini. Zoological Magazine, 12, 379-405. [In Japanese]

Yoshiwara, S. (1901) Echinoids of Okinawajima Islands and Amami Islands. Zoological Magazine, 13, 172-174. [In Japanese] 